\title{
„WIELKIE UPROSZCZENIE” \\ I „DRYFUJĄCE SACRUM”. ANGEL-A LUCA \\ BESSONA JAKO POPKULTUROWY APOKRYF
}

MONIKA JAZOWNIK

Wydział Nauk Humanistycznych Uniwersytetu Kardynała Stefana Wyszyńskiego w Warszawie

Department of Humanities Cardinal Stefan Wyszyński University in Warsaw (Poland)

m.jazownik@uksw.edu.pl

Luc Besson, reżyser kojarzony przede wszystkim z kinem akcji, w 2005 roku po sześciu latach przerwy nakręcił film Angel-A. Dla krytyki produkcja ta była nie lada zaskoczeniem - począwszy od gatunku (komedia romantyczna), poprzez stylistykę (melancholijny nastrój, czarno-biała kolorystyka), na tematyce anielskiej skończywszy. Zaskoczenie obrazem Bessona dodatkowo wzmacnia fakt, iż każdy z wymienionych elementów potraktowany został w filmie w sposób przewrotny - ciąży w kierunku swojego rewersu, a dodatkowo nie zawsze chce harmonijnie współgrać z pozostałymi elementami. Wyjątkowość, a raczej swoista „zaczepność” filmu ujawnia się szczególnie dobitnie wtedy, kiedy odbiorca próbuje zorientować się, czy ma do czynienia z filmem „lekkim”, czy poważnym. Niemal do ostatnich scen trudno też wyrobić sobie zdanie co do charakteru poczynań głównej bohaterki.

Obraz Luca Bessona - utwór o prostej, jednak uroczo opowiedzianej fabule, okraszonej pięknymi zdjęciami Paryża i nieoczywistą jak na komedię muzyką - odczytać można jako kolejny błahy film o cudach czynionych przez istoty pochodzące z nieba. Otrzymujemy wówczas melodramatyczną historię o miłości anioła i człowieka, opowieść o pięknie i dobru - wydobytych anielską ręką - które tlą się w każdym człowieku. Można też film ten potraktować rozrywkowo, skupić uwagę na po mistrzowsku nakręconych scenach akcji, utarczkach głównych bohaterów, a muzykę określić jako „klubową” i uznać, że jest ona tylko tłem dla filmowej opowieści o aniele. Można wreszcie zajrzeć pod powierzchnię tej „lekkości przedstawionej”. 
Wtedy okaże się, być może, że Angel-A stanowi artykulację popkulturowych sposobów rozumienia i opisywania świata.

Jak podkreśla badaczka współczesnych narracji apokryficznych, Małgorzata Jankowska: „odwołania do tradycji religijnej [...] kreślą obraz współczesnego człowieka, zagubionego w mnogości przekazów i wartości, rozdartego między przywiązaniem do rozumu a pragnieniem wiary, człowieka niepewnego swej konstytucji w świecie post mortem Dei"1. Jakkolwiek dzieło Bessona intencjonalnie filmem religijnym $\mathrm{z}$ pewnością nie jest, to jednak niewątpliwie wskazuje na te momenty egzystencji, które naznaczone są „niewytłumaczalnością” i pozostają niejako zakryte dla ludzkiego rozumu. Historie znane z Biblii niejednokrotnie odnajdują swoje odbicie w filmie twórcy Nikity. Ostatecznie kontekstem dla rozważań o apokryficznej naturze twórczości Bessona warto uczynić - jak już wspomniano - religię, rozumianą tutaj jako „systemem działań, wierzeń, symboli, wartości, praktyk, które podporządkowują wymiar ziemski wymiarowi pozaziemskiemu"2. Dodajmy, iż opisywany i definiowany przez religię porządek świata ożywiany jest przez pamięć. Ta z kolei przywołuje przeszłość „pulsującą” w teraźniejszości. Pamięć religijna uruchamia ponadto (czy raczej prowokuje) wyobraźnię, która zasadza się na paradoksalności i antynomiczności Tajemnicy (Tajemnic Boskich). Twórczy „nerw” wyobraźni, jak również jej zdolność do tworzenia, odtwarzania i uzupełniania przeszłości, w znakomity sposób łączy się z cechami charakterystycznymi dla apokryfu, takimi jak: komentowanie, naśladowanie, krytykowanie ${ }^{3}$. Dodajmy jeszcze jedną cechę - oswajanie - a otrzymamy strategię doskonałą, przełamującą ciężar doświadczenia numinotycznego. Film Luca Bessona Angel-A byłby zatem przykładem popkulturowego zabiegu „oswajającego” świadomość drastycznej asymetrii między tym, co definiowalne, a tym, co rozpływa się w „duchowej topografii”. Strategia ta - z definicji apokryficzna - zapewnić ma w tym przypadku komfort i poczucie bezpieczeństwa u odbiorcy.

1 M. Jankowska, Narracje apokryficzne w kulturze współczesnej, Poznań 2011, s. 13.

2 Sformułowanie Rolanda Robertsona, [cyt. za:] D. Hervieu-Leger, Religia jako pamięć, tłum. M. Bielawska, Kraków 1999, s. 11.

3 M. Jankowska, op. cit., s. 31. 
Kiedy przyglądamy się współczesnej kulturze (szczególnie popularnej), zauważyć możemy, iż pamięć (zwłaszcza religijna) poddawana jest swoistej fragmentaryzacji - drobne elementy owej pamięci mogą być dowolnie łączone, „zszywane” ze sobą za pomocą różnych technik. Adam Regiewicz, analizując filmy popkulturowe, posługuje się kategorią patchworku ${ }^{4}$. Niewątpliwie owa patchworkowa tendencja znajduje również odbicie w popkulturowym apokryfie. Kultura popularna dodatkowo zaprawia tę pamięć właściwymi sobie „konserwantami”, takimi jak lekkość, łatwość i przyjemność, a przez to pozbawia ją szlachetnej trwałości. Marzy się jej bowiem świat prosty i kolorowy, taki, który ogarnąć można jednym spojrzeniem. Zygmunt Bauman mówi w tym kontekście o „wielkim uproszczeniu” jako dotkliwej psychozie naszych czasów ${ }^{5}$.

4 „Film jest typowym patchworkiem kulturowym, w którym elementy chrześcijańskie przeplatane z pogańskimi wierzeniami, buddyjską reinkarnacją i sekularnością tworzą [swoisty - przy. M.J.] hamburger - łatwy do przełknięcia, ale ciężkostrawny. [Patchwork - przyp. M.J.] wpisuje się tym samym w koncepcję New Age, którą można porównać do religijnego supermarketu, gdzie każdy może swobodnie wybierać i wkładać do koszyka potrzebne mu artykuły"; A. Regiewicz, Kino a kultura $w$ świetle antropologii wspótczesnej. Próba interpretacji kerygmatycznej, Lublin 2011, s. 108. Podobnie Urszula Jarecka w artykule dotyczącym figur aniołów w kulturze popularnej podkreśla niewątpliwy wpływ New Age na ich wizerunek. Zob. U. Jarecka, Świeckie „Anioły”. Wyobrażenia para-anielskie w kulturze popularnej, [w:] Religijność w dobie popkultury, red. T. Chachulski, J. Snopek, M. Ślusarska, Warszawa 2014, s. 146-172. Szerzej na temat atrakcyjności New Age dla kultury popularnej zob. W. Jedynak, Neopogański ruch New Age - zagrożenia dla życia religijnego, Niepokalanów 1995. Dariusz Czaja winą za taki stan obarcza w znacznej mierze Kościół katolicki. Jak pisze: „katolicyzm [...] doprowadził również w warstwie wizualnej do infantylizacji postaci anioła. Wyposażone w parę złotych skrzydeł pyzate putta o różowych policzkach, polatujące w przestrzeni barokowych kaplic i kościołów, są tego procesu jednoznacznym świadectwem oraz wyraźnym dowodem na to, że anioły coraz bardziej odsuwano w sferę bytów umownych, nierzeczywistych, nieznajdujących miejsca w autentycznym i żywym przeżyciu religijnym". D. Czaja, Anioł Stróż w filmowym kadrze. O kiczu religijnym, [w: ] Niedyskretny urok kiczu, red. G. Stachówna, Kraków 1997, s. 128.

5 Zob. Z. Bauman, Dwa szkice o moralności ponowoczesnej, Warszawa 1994, s. 38 . 
Ostatecznie przyjąć należy, że film Luca Bessona stanowi przykład zastosowania popkulturowej strategii apokryficznej, w myśl której najpierw ustala się, kim/czym anioł mógłby być (czyli jakie cechy anioła „kanonicznego" ${ }^{\prime 6}$ są do zaakceptowania), a następnie proponuje taki wizerunek anioła, w którym relewantność dodanych lub odjętych mu przymiotów określana jest ze względu na popkulturowy model postrzegania rzeczywistości.

Dariusz Czaja zauważa, że zainteresowanie kina popularnego tematyką

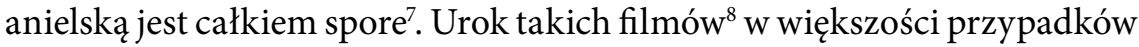

${ }^{6}$ Ireneusz Kania podkreśla, że ontologia anielska pełna jest miejsc niejasnych. I. Kania, Do czego sq nam potrzebne anioły?, „Magazyn Kulturalny Tygodnika Powszechnego" 1998, nr 1-2, dostępny online: http://www.tygodnik.com.pl/kontrapunkt/19-20/kania.html [data dostępu: 27.08.16]. Andrei Pleşu pisze z kolei, że: „Istnieją zdania de fide lub fidei proxima - czyli prawdy pewne lub prawdy akceptowalne jako artykuły wiary. Na tej płaszczyźnie dogmatycznej przyjmuje się na przykład, że istnieją anioły, że Bóg wysyła je w celu służenia ludziom i chronienia ich, oraz że istnieją anioły stróże opiekujące się danym człowiekiem przez całe jego życie. Zdań tych nie można zakwestionować bez ryzyka wypadnięcia poza granice wiary. Bardzo solidne, dobrze ugruntowane teologicznie [...] są zdania saltem theologica certa. Przykładem takiego zdania jest to, które mówi, że tylko ludzie wierzący mają własnego anioła stróża. Ci, którzy wierzą, że każdy człowiek wierzący lub nie ma swojego anioła stróża, sytuują się na skromniejszym, ale ciągle możliwym do udowodnienia poziomie pewności: sententia communis”. A. Pleşu, O aniołach, tłum. T. Kalinowski, Kraków 2003, s. 68.

7 Zob. D. Czaja, op. cit., s. 132. Warto wymienić tu kilka filmów, w których występują postaci aniołów: Anioł na ziemi (Earth Angel, reż. J. Napolitano, 1991), Prawie jak Anioł (Almost an Angel, reż. J. Cornell, 1990), Rezerwowy Anioł Stróż (Angels in the Outfield, reż. W. Dear, 1994), Anioł Stróż (Les Anges Gardiens, reż. J.M. Poire, 1995), Mój anioł stróż (The Angel Levine, reż. J. Kadár, 1970), Żona biskupa (The Bishop's Wife, reż. H. Koster, 1947), Facet z nieba (The Heavenly Kid, reż. C. Medoway, 1985), Michael (Michael, reż. N. Ephron, 1997), Życie mniej zwyczajne (A Life less Ordinary, reż. D. Boyle, 1997).

8 Uściślić trzeba, iż nie interesują mnie tutaj anioły zła, zagłady, anioły karzące, będące domeną filmów utrzymanych najczęściej w konwencji horroru, czerpiących inspiracje z wątków apokaliptycznych. 
polega na tym, że anielski czar i cudowność uobecnia się w szarościach profanum i rozświetla je. $\mathrm{W}$ dziełach tych widać przede wszystkim odwołania do religijności potocznej, co wynika między innymi z tego, że kultura popularna jest w dużej mierze zestandaryzowana, powierzchowna, oparta na powtórzeniach.

Obraz francuskiego reżysera potraktować można jako swego rodzaju synekdochę twórczości filmowej o tematyce anielskiej, jednakże Angel-A naznaczony jest ambicjami apokryficznymi w znacznie większym stopniu niż wiele innych dzieł o istotach z nieba. Nie sposób nie zauważyć, iż gros scen kluczowych dla jego wymowy rozgrywa się nad rzeką lub w miejscach związanych z wodą, takich jak most, fontanna, łaźnia miejska czy łazienka w klubie disco. Jakkolwiek symbolika wody posiada ugruntowaną pozycję $\mathrm{w}$ wielu religiach (woda ma moc łączenia rzeczywistości doczesnej z nadprzyrodzoną), to jednak w przypadku filmu Bessona symbol ten w istotny sposób uruchamia pole odniesień biblijnych"

Rys ten ujawniony zostaje już w pierwszej scenie, w której dochodzi do spotkania Angeli z André na moście. Swoim desperackim czynem - skokiem do Sekwany - marokański nieszczęśnik zakończyć chce cierpienia, których dźwigać nie ma już siły. Tuż przed swą próbą samobójczą André zauważa na sąsiednim filarze dziewczynę, która - jak się wydaje - ma podobne zamiary. Młody mężczyzna bez zastanowienia rzuca się jej na ratunek. Po chwili oboje, wyczerpani, leżą na brzegu. Warto zwrócić przy tym uwagę, że w wir rzeki rzuca się Angela - nieujawniona jeszcze anielica, która skacze do wody, gdyż wypełnia wyznaczoną jej misję ratowania życia André. To ona porusza wody Sekwany, nadając im w ten sposób wymiar symboliczny. Wspomnieć należy, że dokładnie taki motyw, bodaj jako pierwszy, wykorzystał Frank Capra $\mathrm{w}$ dramacie obyczajowym To wspaniałe życie, nakręconym w roku 1946, jednak w odróżnieniu od filmu Bessona w dziele amerykańskiego reżysera nie posiadał on istotnych konsekwencji fabularnych, a tym bardziej ideowych. W Angel-A nawiązanie do wydarzeń opisywanych w Ewangelii

9 Warto wymienić tutaj najważniejsze fragmenty, które tę symbolikę wykorzystują: woda jako część dzieła stworzenia (Rdz 1, 1-2), wody Potopu (Rdz 6-8), przejście Izraelitów przez Morze Czerwone (Wj 14, 21-31), nieposłuszeństwo Jonasza, za które prorok zostaje wrzucony do wody (Jon 1, 13-16), Jezus - źródło Wody Żywej (J 4, 13-14). 
św. Jana jest na tyle jaskrawe, przekonujące i umotywowane, że warto przeanalizować Bessonowski apokryf w odniesieniu do tego właśnie tekstu. Mowa tam o sadzawce zwanej Betesda, nad którą leżeli cierpiący, sparaliżowani, „a czekali oni na poruszenie się wody. Anioł bowiem zstępował w stosownym czasie i poruszał wodę. A kto pierwszy wchodził po poruszeniu się wody, doznawał uzdrowienia, niezależnie od tego, na jaką cierpiał chorobę" (J 5, 3-4) ${ }^{10}$. Żywioł wody kojarzony jest w pierwszej kolejności z życiem, dodajmy - nowym życiem. Nie bez znaczenia w tym kontekście pozostaje fakt, że pierwsza i ostatnia sekwencja filmowej opowieści Bessona o spotkaniu człowieka $\mathrm{z}$ aniołem rozgrywa się na moście. Można sadzić, iż zastosowanie takiej klamry kompozycyjnej prowokuje pytanie dotyczące biblijnego „nowego narodzenia” (resp. nowego życia). O ile jednak motyw kąpieli rzecznej w przypadku André wydaje się uzasadniony - odczytywany może być właśnie w kategoriach przemiany życia, poznania, doświadczania w nowy sposób tego, co dotychczas było zakryte - o tyle pomysł na przemienionego anioła jest wyrazem pewnej nonszalancji, z jaką popkultura odnosi się do dogmatyki. Jak trafnie zauważa Don Kupitt: „obszar kultury masowej stał się globalnym targowiskiem, gdzie uprawia się swoisty marketing religijny, sprzedający doktryny, idee, kulty, obietnice zbawienia"l1. Warto dodać, że motyw anioła decydującego się na porzucenie swej niebiańskiej natury również często pojawia się $\mathrm{w}$ filmowych historiach ${ }^{12}$. W dziele Bessona anioł, w odróżnieniu od wielu swych ekranowych poprzedników, nie jest jednak przedstawiony jako stworzenie cierpiące. Reżyser z konsekwentną lekkością zmodyfikował obraz uwięzionego w swej naturze anioła, który ma dosyć swej duchowej egzystencji.

Portret anioła zaproponowany przez Bessona „wypłukany” został z treści, których popkultura nie jest w stanie zaakceptować, a nawet zrozumieć.

10 Wszystkie cytaty z Biblii pochodzą z: Biblia Tysiąclecia. Pismo Święte Starego $i$ Nowego Testamentu, wyd. III, red. A. Jankowski OSB, Poznań 1980.

${ }^{11}$ D. Cupitt, Po Bogu. O przyszłości religii. Od tradycyjnej wiary po nowa wizje religii, tłum. P. Sitarski, Warszawa 1998, s. 10.

12 Wątek anioła, który staje się lub chce zostać człowiekiem, podejmują chociażby filmy: Niebo nad Berlinem (Der Himmel Über Berlin, reż. W. Wenders, 1987), Tak daleko, tak blisko (In weiter, so nah, reż. W. Wenders, 1993), Miasto Aniołów (City of Angels, reż. B. Silberling, 1998). 
Człowiekowi współczesnemu w ogóle trudno przyjąć wiarę w anielski świat. Trudność ta, jak tłumaczy Andrei Pleşu, niekoniecznie wynikać musi z faktu, iż ludzie stali się ateistami lub racjonalistami, lecz z tego, iż pogubili wiarę w porządek boski, czyli harmonijny zbiór opatrznościowych wydarzeń, lub mają o nim niekonsekwentne wyobrażenia ${ }^{13}$. Dodatkowo, „selektywny charakter wierzeń religijnych [...] jest równoznaczny z powiększaniem wątpliwości religijnych"14. Bowiem im dalej od modelu życia proponowanego przez Biblię, tym bardziej rozmazany, a zatem i nieprawdziwy, jawi się obraz Stwórcy, niezmiennego przecież w swej doskonałości ${ }^{15}$. „Człowiek staje wobec sytuacji dryfującego sacrum, w której brak miejsca na teologiczny dyskurs, zastępując go sakralizacją profanum"16. Popkultura chętnie z tego korzysta, propaguje swój model oglądania świata, w którym lansowany jest konsumpcyjny styl życia. W tej sytuacji również obraz anioła podlega ciągłym transformacjom, dopasowuje się do panujących standardów. „Nie wystarczy dziś bowiem, by anioły były "jakieś tam«”. Wymaga się od nich atrakcyjności - mają zaspokajać indywidualne poczucie piękna i spełniać nasze oczekiwania"17. Te popkulturowe oczekiwania zdaje się spełniać również Luc Besson, kiedy odrzuca przekaz tradycji chrześcijańskiej (Biblia, pisma Ojców Kościoła) o aniele jako istocie, która „naśladuje bezcielesne istnienie Boga"18, i zastępuje go aniołem „uczłowieczonym”.

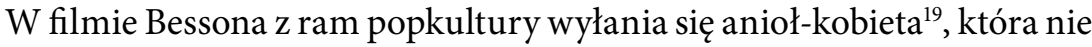
ma nic wspólnego z pełną wdzięku, eteryczną i uduchowioną postacią niebiańską. Angela, dziewczyna o wzroście i figurze modelki ${ }^{20}$, ubrana w bardzo

13 Zob. A. Pleşu, op. cit., s. 75.

14 A. Kudzin, Postać anioła $w$ kulturze popularnej, [w:] Kiczosfery współczesności, red. W. Burszta, E.A. Sekuła, Warszawa 2008, s. 78.

15 „Bądźcie więc doskonali, jak doskonały jest Ojciec wasz niebieski” (Mt 5, 48).

16 A. Regiewicz, op. cit., s. 78.

17 A. Kudzin, op. cit., s. 79.

18 A. Pleşu, op. cit., s. 36.

19 Anioł „kanoniczny” nie ma wieku i nie ma płci, jego feminizacja jest herezją. Zob. ibidem, s. 5.

20 Notabene, aktorka grająca tytułową postać, Rie Rasmussen, jest również modelką o wzroście $178 \mathrm{~cm}$. Fakt ten wykorzystał Besson, by zaznaczyć niezwykłość postaci, w którą się ona wciela. Dodać trzeba, iż ogromna różnica wzrostu między 
krótką i obcisłą czarną sukienkę, zjawia się nagle i nieoczekiwanie, gdy wymaga tego tragiczna i beznadziejna sytuacja, w jakiej znalazł się André. Jakkolwiek ów moment objawienia należy niewątpliwie uznać za najważniejszy w Bessonowskiej historii ${ }^{21}$, to jednak główny bohater, podobnie jak Tobiasz ze Starego Testamentu, nie odczytuje tego zdarzenia w kategoriach Boskiej interwencji ${ }^{22}$. I odczytać nie może, ponieważ na daną chwilę anioł miał za zadanie wcielić się w potrzebującą pomocy kobietę, a wszystko po to, by André mógł poczuć się superbohaterem ${ }^{23}$. Oczywiście anielica z filmu Bessona obdarzona została nadprzyrodzonymi zdolnościami. Nie posiada co prawda skrzydeł, atrybutu istotnego dla ikonografii anielskiej ${ }^{24}$, jest za to nieludzko zaradna i sprytna, a ponadto zadziwiająco beztroska.

Angelą a André hiperbolizuje obraz pary bohaterów, co niewątpliwie wywołuje efekt komiczny.

${ }^{21}$ Ukazywanie się aniołów ludziom to angelofania. Przekazy biblijne mają nie tyle stanowić źródło informacji o naturze niebieskich wysłanników, co być świadectwem anielskich interwencji.

${ }^{22}$ Zmęczony cierpieniem Tobiasz prosi Boga o śmierć. Bóg w miłosierdziu swoim zsyła mu anioła Rafała, który towarzyszy Tobiaszowi w drodze: „Panie, rozkaż, niech będę uwolniony od tej niedoli! Pozwól mi udać się na miejsce wiecznego pobytu [...], ponieważ dla mnie lepiej jest umrzeć, aniżeli przyglądać się wielkiej niedoli w moim życiu i słuchać szyderstw. [...]. I został posłany Rafał, aby uleczyć [...] Tobiasza: aby mu zdjąć bielmo z oczu, tak, aby oczyma swymi znowu oglądać światło Boże" (Tb 3, 6-16).

${ }^{23}$ Kiedy Angela płynie statkiem po Sekwanie z André, wypowiada do niego takie oto słowa: „Uratowałeś mi życie, spełniłeś moje marzenia. Sam widzisz, ze potrafisz uszczęśliwiać ludzi”.

${ }^{24}$ Ten atrybut nie jest potrzebny tytułowej bohaterce. Angela tłumaczy André, że skrzydła są niepraktyczne i mało wygodne. Pojawią się one dopiero wówczas, kiedy misja anielska dobiegnie końca. Notabene, Mały leksykon aniołów informuje, iż skrzydłami obdarzone są tylko serafiny i cherubiny. Ani w Starym, ani w Nowym Testamencie nie znajdziemy słowa o piórach pozostałych aniołów. Warto przypomnieć ponadto, że przekonanie o tym, iż istoty anielskie posiadają skrzydła, zakorzenione jest w wyobraźni symbolicznej. Jeśli bowiem anioł jest pośrednikiem między światem boskim a ludzkim, natomiast oddalenie Boga od człowieka mierzone jest przestrzenią, to owe skrzydła byłyby symbolem prędkości przemieszczania się z miejsca na miejsce, jak też przezwyciężania grawitacji 
Potrafi też zachwycić spektakularnymi popisami, jakich pozazdrościłby jej niejeden iluzjonista. Na prośbę André, który nie wierzy, iż ma przed sobą anioła, Angela niechętnie decyduje się pokazać kilka efektownych trików: wprawia rzeczy w ruch, zmienia ich rozmiary. Zdziwienie André miesza się z fascynacją, uczucie szczęścia z zakłopotaniem. Chciałoby się powiedzieć: „André, uwierzyłeś, bo zobaczyłeś”. W tej próbce cudu chodzi niewątpliwie o wywołanie „efektu fajerwerku”, który ujawnić ma moc nieba w spektakularnej, a zarazem lekkiej odsłonie. „Ekonomia Boża”"25 kieruje się natomiast zgoła innymi prawami. Celem czynionych cudów jest bowiem potwierdzenie i podkreślenie wszechmocy Boga, co z kolei prowadzić ma do umocnienia wiary. Przywołana scena, odczytywana w apokryficznej perspektywie, ujawnia natomiast znamienny, bliski popkulturze stan emocji, stan - dodajmy - prawie że zapalny. Luc Besson łączy tutaj patetyczność $\mathrm{z}$ ckliwością, a gestem tym przełamuje ciężar duchowej przemiany bohatera, zmieniając ją w barwny melodramat.

Podobnie scena, w której niebiańska pomocnica jednym zamaszystym ruchem ręki rozprawia się z dręczycielami André, również skłania do interpretacji zachowań Angeli jako zmodelowanej, popkulturowej wersji aniołów znanych z kart Biblii. Dla nieudacznika życiowego, jakim jest André, wysłanniczka nieba, a zarazem niezależna kobieta odnosząca spektakularne sukcesy, jest niedoścignionym wzorem. Relacja, jaka łączy Angelę z André, wpisuje się w charakterystyczny dla popkultury model idol - fan. Marokański emigrant o niedojrzałej osobowości nie jest w stanie w żaden sposób dorównać swojej przewodniczce, nie ma nawet takich aspiracji. Pozycja, którą zajmuje przy jej boku, zapewnia mu bowiem wygodne i spokojne życie, za którym tak tęsknił. Angela z lekkością i łatwością podporządkowuje sobie każdego, kogo zechce, chociaż zdolność ta nie jest przecież jej zasługą. Warto zwrócić uwagę, że reżyserska licentia poetica wypacza tutaj kanoniczy obraz anioła jako istoty czystej w swych intencjach. Proponowany przez reżysera wizerunek anioła wskazuje na typowe dla popkultury postrzeganie świata w duchu relatywizmu, w świetle którego wieloznaczność

ziemskiej. Zob. H. Krauss, Mały leksykon aniołów, tłum. A. Kucharska, Poznań 2009, s. 180.

25 Termin ten zaczerpnięty został $\mathrm{z}$ tytułu książki Witnessa Lee (Anaheim 2003). 
stanowi wartość samą w sobie. W takiej optyce anioł „z nieba rodem” nie musi być krystalicznie czysty, ważne natomiast, by spełnił wyznaczoną mu misję.

Działania bohaterki Bessona koncentrują się całkowicie na André i obejmują cały bagaż jego niepoukładanych spraw - zarówno finansowych, jak i duchowych. Anielica zaczyna swą misję od uregulowania sytuacji materialnej podopiecznego. Pierwszy element, który budzić może niemałe zaskoczenie odbiorcy, dotyczy ziemskiej profesji anioła. Bessonowska Angela została wysłana przecież na ziemię w przebraniu prostytutki, a rolę tę odgrywa nader przekonująco, wyśmienicie się przy tym bawiąc. Jej działania są swawolne, jednak doskonale przemyślane. Przemyślane są również reżyserskie zabiegi, które tworzą przestrzeń gry z oczekiwaniami widza, z lekkością przełamując przy tym kontrowersyjność fabularnego pomysłu. Besson chętnie i w sposób wyrafinowany korzysta z elipsy, kiedy z rzeczywistości przedstawionej na ekranie usuwa obrazy praktyk prostytuowania się Angeli. Bo jakkolwiek wcześniejsze sceny wyraźnie naprowadzają widza na ten myślowy trop, a warstwa dźwiękowa dobitnie go potwierdza i przypieczętowuje (miarowe odgłosy dobiegające $\mathrm{z}$ klubowej toalety), to jednak w dalszym toku akcji okazuje się, że zarówno bohater, jak i widz mylili się co do charakteru tego zajścia (dźwięki towarzyszące tej scenie miały inne źródło pochodzenia, niż wyobrażał to sobie odbiorca). Podobny efekt niespodzianki ma miejsce wtedy, kiedy Angela po spotkaniu z szefem mafii przekazuje André efekt swojej „pracy”. W tym przypadku przed widzem również ukryte zostały rzeczywiste czyny Angeli, która - jak się później okaże - nie zarobiła pieniędzy, lecz je ukradła.

Znamienne w Bessonowskim filmie jest to, że działania, które powszechnie nie są akceptowalne, w rzeczywistości przedstawionej na ekranie akceptację ową zyskują. Tak dzieje się w przypadku scen naznaczonych przemocą czy brutalnością. Angela nie tylko używa swego zaprawionego sprytem wdzięku i skutecznie negocjuje warunki umowy z wierzycielami André, ale dodatkowo też rozprawia się z nimi w popisowo gangsterskim stylu. Przemoc tę Besson oswaja czy neutralizuje, co daje efekt lekkiej zabawy i pikantnego humoru.

Warto zwrócić uwagę, iż sposób wypełniania przez Angelę powierzonej jej misji opiekuńczej niewątpliwie kłóci się wyobrażeniami o działaniach 
anioła „kanonicznego”26. Angela przypomina raczej wojowniczą i bezkompromisową Larę Croft - popkulturową bohaterkę komiksów i gier komputerowych. Przyznać trzeba, iż tytułowa bohaterka filmu Bessona wyznaczoną jej rolę stróża-wyzwoliciela wypełnia z prowokacyjną nonszalancją, a wszelkie działania wykonuje bez cienia żarliwości, która uchodzi za domenę świata ducha. Z drugiej jednak strony, jeśli sięgniemy do greckiej etymologii słowa 'anioł', oznaczającego 'posła' lub 'wysłannika', to okaże się, że zadania związane z pełnieniem tej posługi Angela realizuje nienagannie, a kunszt dyplomacji opanowany ma również w najwyższym stopniu. Tradycja Kościoła uczy, iż aniołom powierzone zostały cztery funkcje: doradcy, nauczyciela, obrońcy i przewodnika. Najważniejszym natomiast ich celem jest nadanie podopiecznemu właściwego kierunku jego ziemskiej wędrówki ${ }^{27}$. To właściwe ukierunkowanie nastawione ma być na poznanie dobra $^{28}$. W pedagogice boskiej okazuje się nierzadko, że anielskie prowadzenie - a zatem takież rozumienie dobra - nie pokrywa się z naszymi, ziemskimi wyobrażeniami, co bywa dla człowieka bolesnym doświadczeniem. Trud dźwigania przeciwności losu, jak też pokorne jego przeżywanie, może zaowocować ostatecznie wyzwoleniem. Jakkolwiek dla popkultury „wolność wewnętrzna” również stanowi niepodważalną wartość, to jednak jest ona inaczej rozumiana niż w teologii. W odróżnieniu od tej ostatniej zawiera bowiem wektor afirmatywny, skierowany na bonum delectabile, a pomijający przeszkody płynące z ciężkich doświadczeń. Tę odciążającą tendencję rozpoznać można w filmie Bessona. Rady i pouczenia, którymi obdarza swojego podopiecznego Niebieska Nauczycielka, nie stawiają w centrum uwagi pracy nad sobą, sprowadzają się natomiast do krzepiącej formuły: „Uwierz w siebie!”. Przykładem takiej lekcji jest scena rozgrywająca się

26 A. Pleşu, powołując się na Pismo Święte, charakteryzuje anioła jako żołnierza i wojownika wyróżniającego się jednocześnie łagodnością, prostotą i miękkością, a cechy te zawarte są w formule „Nie bójcie się!”. A. Pleşu, op. cit., s.93.

27 Zob. ibidem, s. 63.

28 Jan Paweł II pisze o dobru następująco: „na tle metafizycznej, a zarazem antropologicznej wizji dobra kształtuje się podział, który ma już charakter przede wszystkim etyczny. Jest to podział, a raczej rozróżnienie dobra godziwego (bonum honestum), dobra użytecznego (bonum utile) oraz dobra przyjemnego (bonum delectabile)". Jan Paweł II, Pamięć i tożsamość, Kraków 2005, s. 42. 
w publicznej toalecie, podczas której Angela i André z powagą wpatrują się we własne odbicia. Anielica, pragnąc nauczyć André czerpania na nowo radości z życia, przeprowadza swojego wychowanka przez bolesne rejony jego zranionej psychiki. Bohaterom towarzyszy silne wzruszenie, jednak widz nie zostaje nim w szczególny sposób dotknięty, nie doświadcza ciężaru ich emocji. Aleksandra Drzał-Sierocka, znawczyni twórczości filmowej Luca Bessona, tłumaczy ten fakt następująco: „wydaje się, że reżyser nauczył widza obcowania ze stworzoną przez siebie filmową konwencją, [...] konsekwentnie konstruując niejednoznacznych bohaterów i rzeczywistość, w której wizualne piękno spotyka się $\mathrm{z}$ tandetą, a nawet więcej - staje się nią, ubrane w kiczowate dialogi, gesty i schematy fabuły"29.

Wizerunek anioła jako istoty cierpiącej, zagubionej i pozbawionej tożsamości dość często występuje w popkulturowym kinie ${ }^{30}$. I tutaj zauważyć można pewien paradoks, bowiem z jednej strony popkultura chce zagłuszyć realnie istniejące $\mathrm{w}$ świecie cierpienie, odrzuca je, $\mathrm{z}$ drugiej jednak zainteresowana jest bohaterami samotnymi, prawdziwie zagubionymi, wewnętrznie zapętlonymi. Takimi bohaterami są Angela i André, chociaż film Bessona określony został przez krytykę jako komedia. Jego komediowy wymiar zauważalny jest szczególnie w skontrastowanym zestawieniu głównych postaci - począwszy od fizjonomii, na różnicy temperamentów skończywszy. Nierzadko też duch komediowości przychodzi z pomocą wówczas, gdy potrzebne jest oswojenie nieznanego - tego, co z Tajemnicy się poczęło. Wówczas ów śmiech służy osłabieniu stopnia powagi, który trudno jest znieść popkulturowemu widzowi. Bessonowskie przełamywanie patosu zaobserwować można na przykład wtedy, kiedy widzowi ukazany zostaje psychologiczny sekret anielicy. Angela - bohaterka silna, wzbudzająca zachwyt, pewna siebie, bezkompromisowa i atrakcyjna pod każdym względem - bywa jednak dziwnie melancholijna. W jednej ze scen - rozgrywającej się notabene na tle Bazyliki Sacre Coeur przy dźwiękach kościelnych dzwonów - André prosi anielicę o wyjawienie jej życiowej historii. Jakkolwiek początkowo widz spodziewa się ciężkich i trudnych wyznań, które wzbudzą i w nim

29 A. Drzał-Sierocka, Luc Besson. Uśmiechnięta twarz filmowego postmoderni$z m u$, Warszawa 2012, s. 212.

30 Wystarczy wymienić tu takie filmy, jak Miasto aniołów (City of Angels, reż. B. Silberling, 1998) czy Żona pastora (The Preacher's Wife, reż. P. Marshal, 1961). 
współczucie, to jednak już po chwili orientuje się, iż oto reżyser w sposób kokieteryjny nawiązuje z nim dialog. Alternatywne biografie, które Angela wymyśla na poczekaniu, zanurzone są bowiem w wyobraźni potocznej. Dlatego też różnica między prawdą a zmyśleniem przestaje być dla odbiorcy istotna. Biografie możliwe (warstwa obrazowa filmu cofa się tutaj w fikcyjną przeszłość) przytaczane są ponadto zdawkowo za pomocą bardzo szybkich ujęć kręconych „z ręki”, które wywołują efekt lekkości.

I jeszcze jedna odsłona apokryficznej lektury. Anielica w filmie zesłana jest biedakowi jako pomocnik i obrońca. Zjawia się w chwili krytycznej. Jednak propozycja pomocy, z którą przychodzi Angela, nie wynika z jej miłości do nieszczęśnika André. A kanonicznie rzecz ujmując - powinna, bowiem w miłości aniołów do ludzi odbija się przecież miłość Ojca. Ponadto wszystkie działania niebieskich istot czynione są przez Boga i dla Boga. W Bessonowskiej opowieści natomiast André nie jest podopiecznym Angeli, lecz zleconym jej przez Boga (a raczej „szefa”) obiektem interwencji. Angela swoją misję zbawczą traktuje zatem jako pracę, z której będzie rozliczona. Chce więc ją wykonać jak najlepiej, bowiem: „Odrzucenie albo powrót przed końcem misji to klęska dla anioła” ${ }^{31}$. Reżyser tworzy w ten sposób postać anioła kierującego się w swych działaniach przede wszystkim dobrem własnym, co więcej - obciążonego również lękiem o swoje zbawienie, a to - z perspektywy nauki Kościoła - podwójna herezja.

Opisywane przez Angelę niebo również niewiele ma wspólnego z tym, które przedstawiane i obiecywane jest na kartach Biblii. Popkultura bowiem nie jest zainteresowana takim miejscem szczęśliwości, gdzie nieustannie wielbi się Imię Boga i śpiewa psalmy. Wypowiedziane przez tytułową bohaterkę stwierdzenie, że „niebo to sama nuda i rutyna”, dobitnie ukazuje popkulturową wizję tego miejsca. Prawdziwym rajem jest natomiast ziemia, i to tu warto zostać. Angela Bessona odczuwa silną potrzebę zabawy, która „jest niezbędna do zwalczania podstawowego egzystencjalnego problemu nowoczesności - nudy"32. Anielica spragniona jest ziemskich przyjemności i człowieczych doznań - najlepiej czuje się w klubie dyskotekowym, chętnie

31 Te słowa wyznaje Angela swojemu podopiecznemu, kiedy ten nie chce uwierzyć w jej anielskie pochodzenie.

32 J.E. Combs, Świat zabaw. Narodziny nowego wieku ludycznego, tłum. O. Kaczmarek, Warszawa 2011 s. 108. 
bierze udział w wyścigach konnych, lubi klimat paryskiej kawiarni, wreszcie doskonale spełnia się $\mathrm{w}$ roli prostytutki. Wybiera miejsca, w których tętni życie, ponieważ jej osobiste pragnienie to przełamanie nudy, owej smętnej, ciemnej materii, uciążliwie przenikającej egzystencję ${ }^{33}$.

Jedna z końcowych scen filmu - bardzo dramatyczna - prezentuje anielicę zagubioną w swoich decyzjach, gotową renegocjować swoje normy i wybory ${ }^{34}$ właśnie ze względu na pragnienie uczestnictwa w ziemskim, cielesnym, a zatem - lepszym bycie. Skrzydła, które unosić ją mają w niebiańskie przestrzenie, stają się dla Angeli udręką, wydają się cięższe od niej samej, unoszą ją w górę wbrew jej woli. Anielica panicznie nie chce powrotu do nieba, a jednocześnie wie, że zostać na ziemi nie może. Zdaje się, że utraciła zmysł orientacji, niebiańską zdolność widzenia wyraźnie. $\mathrm{Z}$ pomocą przychodzi jej André, który proponuje, by chociaż na chwile zapomniała o Bogu. Zapomnieć - a raczej zapomnieć się - w języku popkultury znaczy tyle, co dać się ponieść chwili, nie zważając na konsekwencje swoich czynów. Warto zauważyć, że nie pierwszy raz w filmie Besson nie tyle podważa, co problematyzuje, gmatwa kwestię anielskiej szlachetności, jak również poddaje w wątpliwość archetypiczny podział rzeczywistości na jasną i ciemną, tę „,z góry” i tę „z dołu”. Kiedy bowiem w przywołanej scenie anielica przystaje na propozycję André i zatraca się w pocałunku, nagle $\mathrm{z}$ ramion boleśnie wyrastają jej białe skrzydła, które szarpią czarną sukienkę. W tym momencie oczy niebiańskiej wysłanniczki wyraźnie zmieniają swój wygląd, stają się złowieszcze, wręcz demoniczne. Moment wzbijania się Angeli ku górze pozostawia widza z pytaniem o najszczęśliwsze miejsce bytowania istot niebieskich.

W Angel-A istnieje pewna wyczuwalna aura tajemniczości, która nie przystaje do całości filmu, zwłaszcza że dzieło Bessona posiada wyraźne elementy gangsterskie i komediowe. Ten niepasujący aspekt ujawnia się chociażby w muzycznej warstwie filmu - w ambientowym ${ }^{35}$, „przydymionym” nastroju kompozycji Anji Garbarek doszukać się można dźwigania ciężaru

33 Ibidem. s.109.

34 Według nauczania Kościoła aniołowie pierwszy i ostatni raz dokonali wyboru na początku świata. Zob. A. Pleşu, op. cit., s. 18.

35 Ambient to gatunek muzyki elektronicznej, w której istotną rolę odgrywa barwa dźwięku. 
harmonii anielskich bytów ${ }^{36}$. Ta przewrotna muzyczna metafora wyrażać mogłaby napięcie między ziemskim światem a anielską jasnością poznania ${ }^{37}$, bowiem niebiańska „muzyka nie jest [tylko] marginalnym ornamentem światła, ale jego sposobem bycia, jego modelem, [...] żywym porządkiem"38, który pitagorejczycy określali jako „muzyka sfer”. Należy zauważyć, że większość utworów skomponowanych do filmu Angel-A utrzymana jest w tonacji molowej, która zakłóca lekką wymowę filmu. Melodyka tych kompozycji wykazuje ponadto predylekcję do pochodów chromatycznych, co wpływa na jej dysonansowość. Warto wspomnieć, że utwory Anji Garbarek posiadają strukturę łukową, o słabo zaznaczonej kantylenie. Charakteryzują się ponadto wolnym tempem i długimi wartościami rytmicznymi. Podobnie tajemniczo-nostalgiczny nastrój ujawnia się $\mathrm{w}$ warstwie wizualnej dzieła Bessona. Urzekający od pierwszych scen - pochodzący jakby nie z tego świata - minimalistyczny światłocień szarych barw niejako nie pozwala wybrzmieć jasności, która kojarzona jest $\mathrm{z}$ aniołami. Istoty anielskie „pojawiają się jako snop błyszczących iskier (scintillae), grawitujących wokół pierwotnego Ognia"39 i stanowią odbicie Boskiego Światła. Zatem nie tylko muzyczny „puls”, ale także dominująca kolorystyka pozostaje w kontrze do pozytywnego, optymistycznego przesłania filmu. Szarość nie należy przecież do barw, które kojarzyć można z wyzwoleniem, pokojem, lekkością anioła rozświetlonego bożą jasnością. Szarość - tłumiąca czerń czy brudząca

36 Warto zwrócić uwagę na utwór Her Room, który stanowi niewątpliwie muzyczny motyw przewodni filmu. Harmonia w tym utworze oparta jest na brzmieniach kwartowo-kwintowych. Interwały te uznawane były w średniowiecznej teorii muzyki za doskonałe pod względem proporcji i brzmienia.

37 Pieśni aniołów mają związek z poznaniem, o czym pisze Hildegarda z Bingen $\mathrm{w}$ Liber divinorum operum, gdzie mowa jest o anielskim wysławianiu Boga w dziele stworzenia. Jak stwierdza Błażej Matusiak: „Śpiew aniołów jest kontemplacją Boga, zarówno w nim samym, jak i w Jego stworzeniu. Im dokładniej aniołowie poznają Boga, tym wyraźniej widzą, że nie mogą Go ogarnąć. Pieśń aniołów jest paradoksalnie jednocześnie jednostajna i wciąż nowa. Odkrywając w Bogu coraz to nowe piękno, aniołowie dodają do swej pieśni nowe motywy”. B. Matusiak, Hildegarda $z$ Bingen. Teologia muzyki, Kraków 2003, s. 33.

38 A. Drzał-Sierocka, op. cit., s. 123.

39 Ibidem s. 122. 
biel - ostatecznie nosi w sobie ciężar pewnego zagubienia, spopielenia. Tak ukształtowane elementy dzieła tworzą melancholijny nastrój, w który wpisany jest, być może, smutek utraty jasności oraz tęsknota za słowami Stwórcy: „Fiat lux!”40. Można postawić pytanie - znakiem jakiego świata jest urzekający światłocień i ta nastrojowa muzyka?

Wątpliwość, z którą zostawia tutaj widza twórca Wielkiego błękitu, wynikać może z pewnego zakłócenia między treścią a formą dzieła. Zakłócenie to stanowi niewątpliwy walor filmu, wyróżnia go spośród innych dzieł o tematyce anielskiej. Z drugiej jednak strony, gdyby pominąć odwołanie do owej biblijnej „swoistości anielskiej”, gdzie światło i muzyka są żywiołami, w których udział mają niebieskie istoty, to dzieło Bessona nic nie traci na swym ideowym potencjale czy artystycznej mocy. Nastrój, jaki niosą muzyka i obraz w Angel-A, posiadać będzie status tła, ostatecznie kojarzonego z Tajemnicą.

Apokryf Luca Bessona stanowi wyraz popkulturowego postrzegania świata, w które wpisane jest prawo do wyrażania i promowania mocno uproszczonych treści religijnych. Postawa ta stanowi artykulację jawnego i otwartego konfliktu między kulturą popularną a religią. W swojej „katechezie świata"41 (tego świata), w którą obraz twórcy Joanny d’Arc się wpisuje, biblijne prawdy wiary zręcznym gestem przepuszczone zostają przez filtr popkultury i kształtowane są według jej standardów. Film Bessona stanowi tym samym swoistą dokumentację współczesnego myślenia o tych aspektach czy momentach życia człowieka, które niewątpliwie w metafizyce są zanurzone (i tam jest ich właściwe miejsce). Popkultura sprawy te jednak z owej metafizyki - ciężkiej i uwierającej - chce wydobyć. A robi to z lekkim uśmiechem i przecież nie bez swego rodzaju wdzięku. Jak pisze Aleksandra Drzał-Sierocka:

Luc Besson nie próbuje sensów na powrót zespalać, nie udaje, że przekazuje w dziele prawdę: o świecie, [...] o człowieku. Ma do siebie dystans i mruga

40 „Niech się stanie światło” ( $\operatorname{Rdz} 1,3)$.

${ }^{41}$ A. Regiewicz, op. cit., s. 29. 
do widza z ekranu. Odbiorca, jeśli zechce, wyłowi to mrugnięcie, ale nic na siłę. Najwyraźniej głos takiego autora usłyszy widz-schizofrenik, szczególnie otwarty na wielość, umiejący wyłowić aluzje i cytaty, ale też akceptujący kolaż jako metodę twórczą; widz, który zechce zagrać z twórcą w twórcze kino ${ }^{42}$.

\section{Bibliografia}

Biblia Tysiąclecia. Pismo Święte Starego i Nowego Testamentu, wyd. III, red. O. Augustyn Jankowski OSB, Pallotinum, Poznań 1980.

Zygmunt Bauman, Dwa szkice o moralności ponowoczesnej, Instytut Kultury, Warszawa 1994.

James E. Combs, Świat zabaw. Narodziny nowego wieku ludycznego, tłum. O. Kaczmarek, Wydawnictwo UW, Warszawa 2011.

Don Cupitt, Po Bogu. O przyszłości religii. Od tradycyjnej wiary po nowa wizję religii, tłum. P. Sitarski, W.A.B., Warszawa 1998.

Dariusz Czaja, Anioł Stróż w filmowym kadrze. O kiczu religijnym, [w:] Niedyskretny urok kiczu, red. G. Stachówna, Universitas, Kraków 1997.

Aleksandra Drzał-Sierocka, Luc Besson. Uśmiechnięta twarz filmowego postmodernizmu, Wydawnictwo Akademickie Sedno, Warszawa 2012.

Danièle Hervieu-Léger, Religia jako pamięć, tłum. M. Bielawska, Nomos, Kraków 1999.

Małgorzata Jankowska, Narracje apokryficzne w kulturze współczesnej, Wydawnictwo UAM, Poznań 2011.

Urszula Jarecka, Świeckie „Anioły”. Wyobrażenia para-anielskie w kulturze popularnej, [w:] Religijność w dobie popkultury, red. T. Chachulski, J. Snopek, M. Ślusarska, Wydawnictwo UKSW, Warszawa 2014.

Witold Jedynak, Neopogański ruch New Age - zagrożenia dla życia religijnego, Wydawnictwo Ojców Franciszkanów, Niepokalanów 1995.

Heinrich Krauss, Mały leksykon aniołów, tłum. A. Kucharska, Księgarnia św. Wojciecha, Poznań 2009.

Aleksandra Kudzin, Postać anioła w kulturze popularnej, [w:] Kiczosfery współczesności, red. W. Burszta, E.A. Sekuła, Wydawnictwo SWPS, Warszawa 2008. Witness Lee, Ekonomia Boża, Living Stream Ministry, Anaheim 2003. Błażej Matusiak OP, Hildegarda z Bingen. Teologia muzyki, Kraków 2003.

${ }^{42}$ A. Drzał-Sierocka, op. cit., s. 51. 
Andrei Pleşu, O aniołach, tłum. T. Kalinowski, Homini, Kraków 2003.

Adam Regiewicz, Kino a kultura w świetle antropologii współczesnej. Próba interpretacji kerygmatycznej, Norbertinum, Lublin 2011.

\section{The Film Angel-A by Luc Besson as Pop-culture Apocrypha}

Apocrypha as testimony of non-canonical reading of sacred texts can provide a starting point for a discussion on works of popular culture. Luc Besson's film Angel-A, as a kind of synecdoche of filmmaking about angels illustrates in a vivid, pop-culture way the trends of understanding and describing reality. The director's portrait of the angel, much different from that proposed by the Bible, promotes a model of the world which provides a sense of freedom and lightness. In the end, however, does pop-culture have the power to release us from the weight of secrecy? It seems that everyone must experience that for themselves...

Keywords: Luc Besson, angels, pop-culture, modern apocrypha, metaphysics 